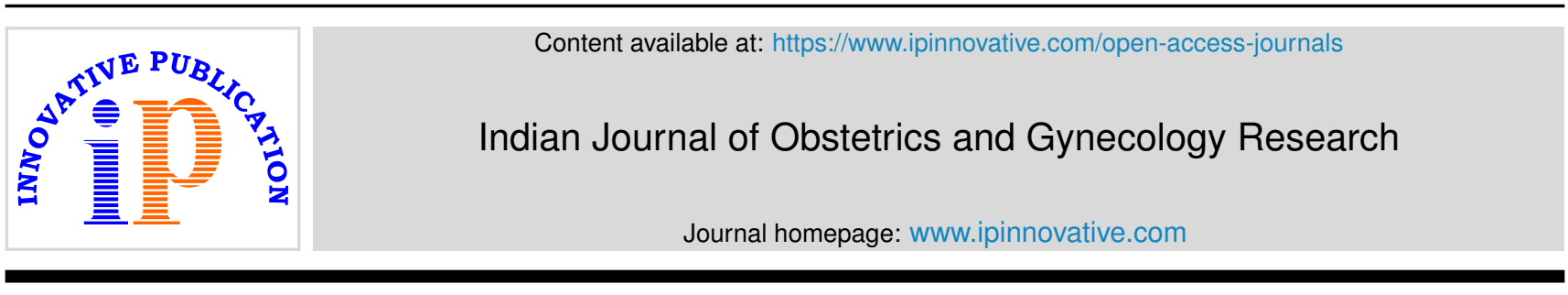

Original Research Article

\title{
Abnormal uterine bleeding in perimenopausal women: Clinical histopathological and sonography correlation
}

\author{
Shahana Ishaq Chandniwala ${ }^{1, *}$, Mahima Jain ${ }^{1}$ \\ ${ }^{1}$ Dept. of Obstetrics and Gynaecology, B.J. Medical College and Civil Hospital, Ahmedabad, Gujarat, India
}

\section{A R T I C L E I N F O}

\section{Article history:}

Received 10-04-2020

Accepted 09-05-2020

Available online 12-09-2020

\section{Keywords:}

Abnormal uterine bleeding

Menorrhagia

Menometrorrhagia

Polymenorrhea

Ultrasonography

\begin{abstract}
A B S T R A C T
Objective: Patient who underwent hysterectomy for Abnormal Uterine Bleeding their clinical findings were related to sonography and histopathology reports.

Materials and Methods: This is retrospective observational study conducted in obstetric and gynaecology department. Patient who have undergone hysterectomy for AUB, their data retrived from case file and their ultrasonography reports and histopathological examination reports were compared.

Results: 153 women who have under gone hysterectomy had complaint of menorrhagia and they belong to perimenopausal age group, most of them were between 40-45 years of age. Ultrasonography is suggestive of fibroid in most of the patients and it is most sensitive for diagnosis of uterine fibroid.

Conclusion: Fibroid is a most common cause of AUB. Clinical, sonography and histopathological findings correlated well with the diagnosis.

(C) 2020 Published by Innovative Publication. This is an open access article under the CC BY-NC license (https://creativecommons.org/licenses/by-nc/4.0/)

\begin{tabular}{ll}
\hline $\begin{array}{l}\text { Structural causes } \\
\text { (PALM) }\end{array}$ & Nonstructural causes (COEIN) \\
Polyps & Coagulopathy \\
Adenomyosis & Ovulatory dysfunction \\
Leiomyomas & Endometrial \\
Submucosa & (Primary disorder of mechanisms \\
Others & regulating endometrial hemostasis) \\
Malignancy and & Iatrogenic \\
hyperplasia & Not yet specified \\
\hline
\end{tabular}
\end{abstract}

\section{Introduction}

Abnormality in frequency, regularity, duration or volume of bleeding in women of reproductive age is called Abnormal Uterine Bleeding (AUB). Quality of life is affected as it is associated with pain and discomfort. AUB leads to loss of productivity ${ }^{1}$ and may result in surgical intervention including hysterectomy. ${ }^{2}$ AUB affects 9 to $14 \%$ women between menarche and menopause. ${ }^{3}$ In India, the reported prevalence is around $17.9 \% .{ }^{4}$ AUB patterns include menorrhagia, metrorrhagia, polymenorrhea, dysfunctional uterine bleeding and heavy menstrual bleeding.

To standardize nomenclature of AUB a system known by acronym PALM-COEIN was introduced in 2011 by FIGO. ${ }^{5}$

Normal and abnormal parameters of menstruation parameters are characterized under FIGO nomenclature.

\footnotetext{
* Corresponding author.

E-mail address: shahanachandniwala@gmail.com (S. I. Chandniwala).
}

\section{Materials and Methods}

Retrospective observational study was conducted in B.J. Medical college, Ahmedabad, Gujarat from august 2019 to January 2020 (6 months). Total 153 cases were analyzed. History and clinical findings were. ultrasonographic evaluation was done in all patients. The clinical fiindings ultrasonographic findings were correlated. Histopathology examination reports were correlated with sonographic reports. 


\begin{tabular}{|c|c|c|}
\hline $\begin{array}{l}\text { Clinical } \\
\text { dimension of } \\
\text { menstrual cycle } \\
\text { and menses }\end{array}$ & Term & $\begin{array}{l}\text { Normal limits } \\
\text { (5th }-95 \text { th } \\
\text { percentiles })\end{array}$ \\
\hline \multirow{3}{*}{ Frequency } & Frequent & $<24$ days \\
\hline & Normal & 24-38 days \\
\hline & Infrequent & $>38$ days \\
\hline \multirow{5}{*}{$\begin{array}{l}\text { Regularity: cycle to } \\
\text { cycle variation over } \\
1 \text { year(days) }\end{array}$} & Absent & No bleeding \\
\hline & Regular & Variation $(+/-2-20)$ \\
\hline & Irregular & Variation $>20$ days \\
\hline & Prolonged & \\
\hline & Prolonged & $>8.0$ days \\
\hline \multirow[t]{2}{*}{ Duration of flow } & Normal & 4.5-8.0days \\
\hline & Shortened & $<4.5$ days \\
\hline \multirow{3}{*}{$\begin{array}{l}\text { Volume of monthly } \\
\text { blood loss }\end{array}$} & Heavy & $>80 \mathrm{ml}$ \\
\hline & Normal & $20-80 \mathrm{ml}$ \\
\hline & Light & $<20 \mathrm{ml}$ \\
\hline
\end{tabular}

\subsection{Inclusion criteria}

1. Women in perimenopausal age group with complaint of AUB were included.

2. Women who underwent surgical intervention i e hysterectomy were included.

\subsection{Exclusion criteria}

1. Patient wanted medical management were excluded

2. Patient who under went hysterectomy for reason other than AUB were excluded (eg: endometriosis, mental retardation).

\section{Results}

153 women who underwent hysterectomy in them relation between Age and Parity was compared. Maximum patients are in between 40 and 45 years of age group (67.9\%). It also depicts that chances of AUB increases with Parity.

Table 1: Distribution of parity and age $(n=153)$

\begin{tabular}{lcccc}
\hline Parity & $40-45$ & Years & Total \\
0 & $35-50$ & 1 & 050 & 4 \\
1 & 12 & 2 & 0 & 14 \\
2 & 24 & 2 & 0 & 29 \\
3 & 28 & 9 & 5 & 42 \\
$>=4$ & 37 & 21 & 6 & 64 \\
Total & 104 & 36 & 13 & 153 \\
\hline
\end{tabular}

Majority of patients decides to undergo surgical intervention after 3-6 months of menstrual problem and menorrhagia is dominant symptom. In Indian population they either prefer medical management or donot take any treatment at all.

Histopathology reports of myometrium were suggestive fibroid 74 (48.36\%), adenomyosis 42 (27.45\%), and
Table 2: Distribution of duration and menstrual complaints $(\mathrm{n}=153)$

\begin{tabular}{|c|c|c|c|c|c|}
\hline \multirow{2}{*}{ Complaint } & \multicolumn{4}{|c|}{ Duration(month) } & \multirow{2}{*}{ Total } \\
\hline & $<3$ & 3 to 6 & $\begin{array}{c}\text { 6- to } \\
12\end{array}$ & $>12$ & \\
\hline Menorrhagia & 13 & 38 & 9 & 8 & 68 \\
\hline Polymenorrhoea & 10 & 11 & 4 & 3 & 28 \\
\hline Metrorrhagia & 5 & 16 & 6 & 3 & 30 \\
\hline Menometrorragia & 4 & 9 & 2 & 2 & 17 \\
\hline $\begin{array}{l}\text { Post- } \\
\text { menopausal }\end{array}$ & 4 & 4 & 2 & 0 & 10 \\
\hline Total & 36 & 78 & 23 & 16 & 153 \\
\hline
\end{tabular}

Table 3: Ultrasonography finding $(n=153)$

\begin{tabular}{lc}
\hline Diagnosis & Percentage(\%) \\
Fibroid & $76(49.67)$ \\
Bulky uterus & $31(20.26)$ \\
Adenomyosis & $28(18.30)$ \\
Thickened endometrium & $12(7.84)$ \\
Endometrial Polyp & $4(2.61)$ \\
Malignancy & $2(1.30)$
\end{tabular}

Majority were diagnosed to have fibroid.

normal myometrium 35 (22.87\%). Ultrasonographically 76 fibroid uterus were diagnosed, out of which 69 were confirmed by histopathology, and 7 were adenomyosis. USG diagnosed 28 cases with adenomyosis out of which 26 were confirmed by HPE. USG diagnosed 31 cases as having bulky uterus, which were clinically diagnosed as AUB, in which histopathology report were suggestive of normal myometrium in 18 cases, adenomyosis in 7 , and leiomyoma in 3 cases. 72 cases had hyperplastic endometrium in histopathology report, only 11 were detected in ultrasonography.

\section{Discussion}

Abnormal uterine bleeding is leading cause of hysterectomy in Perimenopausal women. In this study 153 perimenopausal women who underwent hysterectomy were evaluated. Majority of the women were between 40 to 45 years of age with higher parity and most common symptom was Menorrhagia (44.44\%). The study of Jetley et al. ${ }^{6}$ and Shobha, ${ }^{7}$ in which clinical presentation as menorrhagia in AUB evaluation revealed $46.4 \%$ and $46.6 \%$, respectively is comparable to this study.

Ultrasonography is more sensitive for detection of uterine fibroid and less sensitive for Adenomyosis. Whereas, specicificity to diagnose Adenomyosis is comparatively better.

Maximum patient had undergone surgical treatment after suffering for 3 to 6 month (54.98\%) which is similar to the study of Kathuria and Bhatnagar (50\%). ${ }^{8}$

Out of 76 ultrasonographic diagnosed uterine fibroid was $76(49.67 \%) 69$ were confirmed on histopathology report, 
Table 4: Distribution w.r.t. ultrasonography findings and bleeding pattern

\begin{tabular}{lccccc}
\hline USG finding & Menorrhagia & Polymenorrhia & Metrorrhagia & Menometrorrhagia & Postmenopausal \\
Fibroid & 32 & 16 & 13 & 13 & 2 \\
Bulky Uterus & 14 & 6 & 9 & 2 & 0 \\
Adenomyosis & 19 & 3 & 4 & 2 & 0 \\
Thickened & 3 & 3 & 2 & - & 4 \\
endometrium & - & - & 2 & - & 2 \\
Polyp & - & - & - & & 2 \\
Malignancy & - & & & \\
\hline
\end{tabular}

Table 5: Histopathological examination in relation to ultrasonography diagnosis

\begin{tabular}{|c|c|c|c|c|c|c|c|}
\hline \multirow{3}{*}{$\begin{array}{l}\text { USG } \\
\text { Findings }\end{array}$} & \multicolumn{7}{|c|}{ HPE findings } \\
\hline & \multicolumn{3}{|c|}{ Myometrium } & \multicolumn{4}{|c|}{ Endometrium } \\
\hline & Nor mal & $\begin{array}{l}\text { Leomyomatous } \\
\text { changes }\end{array}$ & $\begin{array}{c}\text { Adenomyomatous } \\
\text { changes }\end{array}$ & Proliferative & Secretory & Hyperplastic & $\begin{array}{l}\text { Endometrial } \\
\text { polyp }\end{array}$ \\
\hline $\begin{array}{l}\text { Fibroid } \\
\text { uterus } \\
(n=76)\end{array}$ & - & 69 & 7 & 13 & 16 & 32 & - \\
\hline $\begin{array}{l}\text { Bulky uterus } \\
(\mathrm{n}=31)\end{array}$ & 18 & 3 & 7 & 3 & 7 & 18 & - \\
\hline $\begin{array}{l}\text { Adenomyosis } \\
(\mathrm{n}=28)\end{array}$ & - & 2 & 26 & 7 & 3 & 10 & - \\
\hline $\begin{array}{l}\text { Thickened } \\
\text { endometrium } \\
(n=12)\end{array}$ & 12 & - & 2 & - & - & 11 & - \\
\hline $\begin{array}{l}\text { Endometrial } \\
\text { polyp }(n=4)\end{array}$ & 4 & - & - & - & - & - & 4 \\
\hline $\begin{array}{l}\text { Malignancy } \\
(\mathrm{n}=2)\end{array}$ & 1 & - & - & - & - & 1 & - \\
\hline Total & 35 & 74 & 42 & 23 & 26 & 72 & 4 \\
\hline
\end{tabular}

Table 6: Histopathological examination in relation to ultrasonography diagnosis

USG Findings

Fibroid uterus

$(n=76)$

Bulky uterus

$(\mathrm{n}=31)$

Adenomyosis

$(\mathrm{n}=28)$

Thickened

endometrium

$(\mathrm{n}=12)$

Endometrial

polyp $(n=4)$

Malignancy

$(\mathrm{n}=2)$

Total

\section{Endometrium}

Atrophic Inflammatory Carcinomatous

$$
4
$$

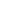

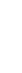

$-$

\section{HPE findings}

Normal
34
13
9
5
3
1
65

\section{Cervix}

Inflammatory 42

18

19

9

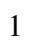

89

8

1
CIN

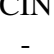

$\begin{array}{ll}- & 1\end{array}$


Table 7:

\begin{tabular}{lcccccc}
\hline $\begin{array}{l}\text { USG } \\
\text { findings }\end{array}$ & Present & Absent & Total & $\begin{array}{c}\text { HPE report } \\
\text { Sensitivity } \\
(\%)\end{array}$ & Specificity (\%) & PPV (\%) \\
Fibroid & 69 & 7 & 76 & 93.24 & 91.13 & 90.78 \\
Present & & 72 & 77 & & & 93.50 \\
Absent & 5 & 2 & 28 & 61.9 & 98.19 & 92.85 \\
$\begin{array}{l}\text { Adenomyosis } \\
\text { Present }\end{array}$ & 26 & 109 & 125 & & & 87.2 \\
Absent & 16 & & & & & \\
\hline
\end{tabular}

and remaining 7 were adenomyosis. The sensitivity of USG for the diagnosis of uterine fibroid is $93.24 \%$, and the specificity is $91.13 \%$, which is comparable to Dueholm et al. ${ }^{9}$

Among 42 cases of Adenomyosis which were diagnosed in histopathology report, only 26 were detected by ulrasonography. Sensitivity of ultrasound for diagnosis of Adenomyosis is low (61.9\%), but specificity is same as compared to the studies of Siedler et al, Ascher et al, and Atri et al. ${ }^{10-12}$ Hence, tissue characterization can be cosidedered as limitation of USG in diagnosis of adenomyosis.

\section{Conclusion}

Leiomyoma is major cause of abnormal uterine bleeding for which hysterectomy is done. Clinical, sonography and histopathological findings correlated well for diagnosis of fibroids. As sensitivity of USG to diagnose Adenomyosis is low therefore, USG alone cannot rule out the diagnosis other modalities should be considered if clinical findings were consistent with Adenomyosis.

\section{Source of Funding}

None.

\section{Conflict of Interest}

None.

\section{References}

1. Cote I, Jacob P, Cumming D. Work loss associated increased menstrual loss in United States. Obstet Gynecol. 2002;100:683-7.

2. Millar WJ. Hysterectomy, 1981/82 to 1996/97. Health Rep. 2001;12:9-22.
3. Fraser IS, Langham S, Uhl-Hochgraeber K. Health-related quality of life and economic burden of abnormal uterine bleeding. Expert Rev Obstet Gynecol. 2009;4(2):179-89.

4. Sharma A, Dogra Y. Trends of AUB in tertiary centre of Shimla hills. J Midlife Health. 2013;4(1):67-8.

5. Munro MG, Critchley HO, Broader MS, Fraser IS. FIGO Working Group on Mensrual Disorder.FIGO classification system (PALMCOEIN) for causes of abnormal uterine bleeding in nongravid women of reproductive age. Int J Gynaecol Obstet. 2011;113:3-13.

6. Jairajpuri ZS, Jetley S, Rana S. Morphological spectrum of endometrial pathology in middle-aged women with atypical uterine bleeding: A study of 219 cases. J Mid-life Health. 2013;4(4):216-20.

7. Shobha PS. Sonographic and histopathological correlation and evaluation of endometrium in perimenopausal women with abnormal uterine bleeding. Int J Reprod Contracept Obstet Gynaecol. 2014;3:113-7.

8. Kathuria R, Bhatnagar B. Correlation between D\&C, USG and hysteroscopy findings in diagnosing a cause for abnormal uterine bleeding. Indian J Clin Pract. 2014;25:466-70.

9. Dueholm M, Lundorf E, Hansen ES, Ledertoug S, Olesen F. Accuracy of magnetic resonance imaging and transvaginal ultrasonography in the diagnosis, mapping, and measurement of uterine myomas. Am J Obstet Gynecol. 2002;186(3):409-15.

10. Siedler D, Laing FC, Jeffrey RB, Wing VW. Uterine adenomyosis. A difficult sonographic diagnosis. J Ultrasound Med. 1987;6(7):345-9.

11. Ascher SM, Arnold LL, Patt RH, Schruefer JJ, Bagley AS, Semelka $\mathrm{RC}$, et al. Adenomyosis: prospective comparison of MR imaging and transvaginal sonography. Radiol. 1994;190(3):803-6.

12. Atri M, Reinhold C, Mehio AR, Chapman WB, Bret PM. Adenomyosis: US Features with Histologic Correlation in an in Vitro Study. Radiol. 2000;215(3):783-90.

\section{Author biography}

Shahana Ishaq Chandniwala 2nd Year Resident

Mahima Jain Professor

Cite this article: Chandniwala SI, Jain M. Abnormal uterine bleeding in perimenopausal women: Clinical histopathological and sonography correlation. Indian J Obstet Gynecol Res 2020;7(3):402-405. 